\title{
TÜRKİYE ve G7 ÜLKELERİNDE BİREYSEL EMEKLİLIKK SİSTEMİ UYGULAMALARI
}

\section{PRIVATE PENSION SYSTEM PRACTICES IN TURKEY and G7 COUNTRIES}

\begin{abstract}
Mehmet ISLAMOĞLU
Hakim $A Z \dot{I} Z^{\dagger}$

ÖZ

Alp KONAK

Bireyler, emeklilik hayatında da hayat standartlarını düşürmeden yaşamlarına devam etmek isterler. Bu amaçla, bireylerin çalışma hayatlarında yapmış oldukları küçük birikimler, emekli oldukları zaman, toplu şekilde veya periyodik ödemeler halinde kendilerine geri ödenir. Ülkemizde bilinen Sosyal Güvenlik Kurumu (SGK) bu görevi üstlenmiş olsa da, yüksek tasarruf açığı nedeniyle, bu işlevi yerine getirme konusunda yetersiz kalmaktadır. Bu sebeple uzun vadeli tasarruf açığının giderilmesi açısından, Bireysel Emeklilik Sistemi (BES) Fonları önemli firsatlar sunmaktadır. Gün geçtikçe sisteme inancın artmasıyla BES Fonları tercih edilen bir yatırım aracı olmuştur. Bu çalışmada, Bireysel Emeklilik Sistemi'nin Türkiye ve G7 ülkelerindeki uygulamaları karşılaştırmalı olarak incelenmiş ve sonrasında BES'in SWOT (GZFT) analizi yapılmıştır. Çalışmada Emeklilik Gözetim Merkezi verilerinden yararlanılarak, katılımcıların sisteme dahil oldukları yaşlar, giriş yıllarına göre dağılımı ve fon tutarları tablolar halinde gösterilmiştir. Sonuç olarak son yıllarda Türkiye'de Bireysel Emeklilik Sistemi, Hükümetin de teşviği ile, gerek fon büyüklügü gerekse katılımcı sayısı olarak önemli bir gelişim göstermiştir.
\end{abstract}

Anahtar Kelimeler: Bireysel Emeklilik Sistemi (BES), Emeklilik Gözetim Merkezi, Tasarruf Jel Kodları: G20,G22,G23

\begin{abstract}
After getting retired, individuals would like to keep their life standards as they had before retirement. For this purpose, small savings that individuals make in their working lives are paid back to them in advance or as periodic payments when they get retired. In our country, Social Security System takes the responsibility to implement this task, but it cannot fulfil its expected duty due to long term saving deficit. So in terms of meeting long term saving deficit, the Private Pension Funds present substantial opportunities. As the system becomes more reliable by time, it has become an appealing investment tool. In this study, Private pension system and its practices are examined comparatively in Turkey and G7 countries and afterwards a SWOT analysis is performed. Using the Retirement Surveillance Center data, the ages of the participants in the system, their distribution according to their inclusion ages and their funding amounts are shown in tables. As a result, in recent years with the incentive of the government in Turkey, Private Pension System has made significant progress in terms of the number of participants as well as fund size.
\end{abstract}

Keywords: Individual Pension System (BES), Pension Supervision Center, Savings

Jel Codes: G20,G22,G23

\footnotetext{
${ }^{*}$ Doç. Dr., Karabük Üniversitesi, İşletme Fakültesi, Finans ve Bankacılık Bölümü, mehmetislamoglu@karabuk.edu.tr ORCID: 0000-0002-4416-0888

${ }^{\dagger}$ Dr. Öğr. Üyesi, Karabük Üniversitesi, İşletme Fakültesi, İşletme Bölümü, hakimaziz@karabuk.edu.tr ORCID: 0000-0002-2566-5784

‡ İşletme Yüksek Lisans Öğrencisi, Karabük Üniversitesi, Lisanüstü Eğitim Enstitüsü, alp.konak@hotmail.com ORCID: 0000-0002-1279-515X
} 


\section{GİRIŞ}

Emeklilik, bilindiği üzere sadece iş hayatının son bulmasıyla ortaya çıkan bir kavram değildir, ancak ülkemizde emeklilik denilince akla gelen ilk şey budur. Halbuki kişiyi emekliliğe iten çeşitli sebepler bulunmaktadır. Kişinin hastalığa yakalanıp işinden ayrılması gerekebilir ya da iş kazası geçirmesi önem arz etmeksizin sakatlanması durumunda da işini kaybetmesi ihtimaller arasındadır. Yaşının dolması sebebiyle işveren tarafından işine son verilebilir. Söz konusu sebeplerden dolayı bireylerin işlerini kaybetmeleri durumunda, gelişmiş ve gelişmekte olan ülkeler, bu vatandaşlarının hayatlarını idame ettirebilmelerini sağlamayı bir yükümlülük olarak kabul etmektedirler. Bunun için de ülkemizde sosyal güvenlik kurumu bu görevi en iyi şekilde yapmayı hedeflemiştir. Ülkemizde kamu kurum ve kuruluşlarında çalışan kişiler emekli olduklarında emekli sandığına, sigortalı bir işte çalışan bireyler Sosyal Sigorta Kurumuna, esnaf ve çiftçiler ise Bağ-Kur'a bağlıyken daha sonraları bütün birimler birleşerek Sosyal Güvenlik Kurumuna bağlanmıştır.

Günümüze gelindiğinde ülkemiz nüfusu ve buna bağlı dinamikleri incelenip, gelişmiş ülkelerle kıyaslama yapıldığında ekonomik nedenler de göz önünde bulundurulursa sosyal güvenlik sistemi maalesef kişileri tatmin etmemektedir. Bundan dolayı özel sigorta şirketleri bu duruma el atmak istemiş ve sosyal güvenlik sistemine destek olmayı hedefleyerek günümüzde kullanılan Bireysel Emeklilik Sistemi olgusunu ortaya çıkarmıştır (Yemez \& Akdoğan, 2019, s. 105).

Bireysel Emeklilik Sistemi, aslında tam anlamıyla sosyal güvenlik sistemini tamamlayıcı bir unsurdur. Katılım, gönüllük esasına dayanan bir sistemken daha sonraları zorunlu olmuştur. Bunun yanında devlet destekleri, vergilerdeki avantajlar ile desteklenerek zamanla tercih edilen bir sistem haline gelmiştir. İlk zamanlar güvenilirliği az olduğu için kişiler yatırım amacıyla sisteme yönelmiş, daha sonraları devletin de teşvikleriyle (devlet katkısı, vergi avantajı) bu sistemin sürdürülebilirliği artmıştır. Katılımcıların ufak da olsa yapmış oldukları yatırımlarının fonlarda değer kazandıklarını görmeleri sonucu, uzun vadede bir kaynak oluşturmuş ve ekonomiye de destek olmuştur. Daha sonra ise bu sisteme dahil olan katılımcılar, burada yapmış oldukları tasarruflarla emekliliğe hak kazandıklarında ekstradan bir gelir elde edecektir. Bu geliri ister belirli süre aylık olarak alabilecek, isterlerse birikimin tamamını süre sonunda alabilecektir. Yani düşük tutarlarla birikim yaparak süre sonunda toplu para ellerine geçebilecektir.

Ülkemizde Bireysel Emeklilik Sistemine giriş ne gönüllük esasına bağlı ne de zorunludur. Otomatik Katılım Sistemi, işletmelerde çalışan kişi sayısı ve yaşlarına göre ilk girişin zorunlu olduğu, ancak katılımcılara isterlerse ilk 2 ay içerisinde sistemden ayrılabilme imkanı sunmaktadır (Apak \& Taşcıyan, 2010, s. 124). Bireyler kazançlarının bir kısmından düzenli kesintiler yapılmasına razı olmak suretiyle, gelecekteki ekonomik refah düzeylerini artırmayı amaçlamaktadırlar. Bu birikim modelini tercih etmeyen bireyler 2 ay içerinde sistemin bağlı olduğu şirketle görüşerek ayrılma taleplerini yazılı olarak bildirdiklerinde maaşlarından her hangi bir kesinti olmayacaktır. Bu çalışmada Türkiye'deki emeklilik sisteminin tarihsel gelişimi ve işleyişi, dünyada bireysel emeklilik sisteminin gelişimi ve G7 ülkelerinde uygulanan bireysel emeklilik sistemi inceleme konusu yapılmıştır.

\section{Türkiye’de Bireysel Emeklilik Sisteminin Gelişimi Ve İşleyişi}

Bireysel emeklilik sisteminin tarihsel gelişimini incelediğimizde; İlk olarak 1997 ile 1999 yılları arasında Hazine Müsteşarlığının denetleyeceği Sosyal Güvenlik Reformuna yönelik çalışmalar başlatılmıştır. SSK, Emekli Sandığı ve Bağ-Kur güvenlik sistemlerinin tek bir çatı alında toplanması yönünde yapılan çalışmalar, 4447 sayılı Kanun ile hükümet tarafından yasalaştırılmıştır. Ayrıca 1999 yılı içerisinde özel emeklilik sistemi için hazırlıklar başlamış, bunun için TBMM'de bireysel emeklilik komisyonu kurulmuştur.

2000’li yıllara gelindiğinde, TBMM Başkanlığına, bireysel emeklilik tasarrufuna ilişkin yatırım tasarısı ve bu tasarıyla oluşacak yeni sistem sunulmuştur. 28 Mart 2001 senesinde bu tasarı TBMM tarafından onaylanmıştır. Onay aldıktan hemen sonra Nisan ayı içerisinde emeklilik tasarruf sistemine ilişkin 24366 sayılı Kanun ve bundan sonra sistemi teşvik eden unsurlardan biri olan vergideki avantaj TBMM tarafından onaylanarak 24458 sayılı yasa kanunları Resmi Gazete'de yayımlanmıştır. 7 Ekim 2001 senesinde sistem yürürlüğe girmiş ve bununla birlikte yatırım yapan katılımcıların, emekliliğe hak kazandıklarında, tasarruflarını isterlerse aylık maaş şeklinde, isterlerse toplu şekilde alabileceklerini ayrıca gelir vergisinin avantajlarından faydalanabileceklerini açık bir şekilde ortaya koymuştur (Seyfullahoğulları \& Demirhan, 2016, s. 28).

Temmuz 2003'te merkezi İstanbul olan BETYSK, Emeklilik Gözetim Merkezi kurulmuştur. Artık şirketlerin kurulmasıyla sistem sorunsuz şekilde ilerleyecektir. Bu bağlamda, 27 Ekim 2003 yılında Ak, Yapı Kredi, Garanti, Anadolu Hayat, Oyak, Koç Allianz Emeklilik ve Hayat Anonim şirketleri faaliyet göstermeye başlamıştır. 2003 
yılının sonuna kadar Ankara, Vakıf, Doğan, Başak Emeklilik A.Ş. ile Commercial Union faaliyete geçmiştir. Sistem ise 27 Ekim 2003 yılında emeklilik planlarının ilk kez onaylanmasıyla birlikte hayata geçmiştir.

2004 yılında emeklilik hayat şirketleri, emeklilik şirketleri, birikimli hayat sigortaları alanında faaliyet gösteren şirketlerin bireysel emeklilik sistemine aktarımına yönelik tebliğ yayımlanmıştır.

2005-2007 yıllarında fonları düzgün şekilde yönlendiren şirketler unvan değişikliğine gitmiştir, bunların başında Doğan Emeklilik A.Ş.'nın unvanı Fortis Emeklilik ve Hayat A.Ş olarak, Başak Emeklilik A.Ş. ise Başak Groupama olarak değişmiştir. Aviva Hayat ve Emeklilik A.Ş., Ak Emeklilik A.Ş. ile birleşerek Avivasa Emeklilik ve Hayat A.Ş. unvanında faaliyetine devam etmiştir.14 Haziran 2007 tarihinde 26552 sayılı Kanun ile 4632 nolu bireysel emeklilik Kanununda madde değişiklikleri yapılmış ve Emeklilik Gözetim Merkezi'nin yetki, sorumluluk ve görevlerinde yeni düzenlemeler yapılmıştır.

2008 yılında sistemin avantajları dikkate alındığında bazı yeni özel şirketler ruhsat almaya başlamıştır, bunların başında Finans Emeklilik ve Hayat A.Ş. gelmektedir, bundan sonra ruhsat alan şirket ise Ergo İsviçre Hayat ve Emeklilik A.Ş. olmuştur. Ankara Emeklilik A.Ş. 26 Eylül 2008 tarihinde Aegon Emeklilik ve Hayat A.Ş. bünyesine dahil olarak ismini değiştirmiştir. 2009 yllına gelindiğinde ise şirketler unvan değişikliklerine devam etmiştir. Koç Allianz; Allianz Hayat ve Emeklilik A.Ş. olarak değişikliğe giderken, Oyak Emeklilik A.Ş.'nin satılmasıyla birlikte ismi ING Emeklilik A.Ş. olarak değişmiştir.21 Mayıs 2009 tarihinde Deniz Emeklilik ve Hayat A.Ș. emeklilik ișlevini yerine getirmek için faaliyet ruhsatını almıștır. Ayrıca yine bu yıl içerisinde Başak Groupama Emeklilik A.Ş. ismini Groupama Emeklilik A.Ş. olarak değiştirmiştir (Emeklilik Gözetim Merkezi, 2020, http://www.egm.org.tr/bireysel-emeklilik/tarihce/ ).

26 Nisan 2010 tarihinde Ergo İsviçre Emeklilik şirketi satılarak Ergo Emeklilik ve Hayat A.Ş. ismini almıştır. 2011 y1lında da faaliyet ruhsatı almaya devam eden şirketler Ziraat Hayat ve Emeklilik A.Ş. ile Axa Hayat ve Emeklilik A.Ş. olmuştur. Yine aynı sene içerisinde Fortis Emeklilik ve Hayat A.Ş.'nin satılmasıyla birlikte yeni adı BNP Paribas Cardif Emeklilik A.Ş. olmuştur.

29 Haziran 2012 yılında sistem ile ilgili çok ciddi kanun değişikliğine gidilmiştir. Bu değişiklikler yatırımcıların sistemden avantajlı bir şekilde getiri elde etmeleri yönünde olmuştur. Devlet katkısı oranı \%25 olarak belirlenmiş ve 18 yaşını doldurmuş her bir katılımcının bu katkıdan faydalanabileceği belirtilmiştir. Katılımcı kendi yatırdığı birikim tutarını şirketler aracıllğıyla yatırıma yönlendirirken, bu değiş̧ikliklerle devlet katkı tutarları da yatırıma yönlenecek, bu şekilde katılımcıların tasarrufları da daha fazla değer kazanmış olacaktır. Bunun yanında devlet katkı tutarları ve getirileri kesinlikle hacze ve rehine konu olmayacaktır. Devlet katkısı ile ilgili alt düzenlemeler de 2012 yılı içerinde yapılmıştır. 1 Ocak 2013 yılından sonra bu düzenlemeler uygulanmaya başlamıştır.

20 Ocak 2012 tarihinde iki şirket daha faaliyet raporu almıştır. Bu şirketler Halk Hayat ve Emeklilik A.Ş. ile Asya Emeklilik ve Hayat A.Ş.'dir.

26 Mart 2012 tarihinde Deniz Emeklilik ve Hayat A.Ş. Amerika'nın en büyük sigorta şirketlerinden biri olan Metlife Emeklilik ve Hayat A.Ş.'ye devrolunarak unvanını değiştirmiştir.

2013 yılında unvanını değiştiren şirketler; Finans Emeklilik, Cigna Finans Emeklilik ve Hayat A.Ş olarak, Yapı Kredi Emeklilik, Allianz Yaşam ve Emeklilik A.Ş olarak değiştirmiştir, Fiba Emeklilik ve Hayat A.Ş. ilk defa bu yıl ruhsatını alırken 2014 yılında Katılım Emeklilik ve Hayat A.Ş . ruhsatını alarak emeklilik faaliyetlerini yerine getirmiştir. 2015 yılında ING Emeklilik A.Ş.'nin satılmasıyla birlikte yeni unvanı NN Hayat ve Emeklilik A.Ş. olmuştur (Emeklilik Gözetim Merkezi, 2020, http://www.egm.org.tr/bireysel-emeklilik/tarihce/) ).

10 Ağustos 2016 yılında ise 6740 sayılı Kanun ile 45 yaşını aşmamış ve 5 kişiden fazla sayıda çalışanı olan işverenler emeklilik şirketleriyle anlaşmalar yaparak, otomatik katılım sözleşmesi yaparak bireysel emeklilik sistemine bu çalışanlarını dahil edebilmeleri yönünde düzenlemeler getirilmiştir. Sistemde kalmak istemeyen çalışanların 2 ay içerisinde sistemden cayma haklarını kullanabilecekleri maddesi de bu kanun içerisine eklenmiştir.

30 Eylül 2016 tarihinde birleşme kararı alan emeklilik şirketleri Ergo Emeklilik ve Fiba Emekliliktir. Bundan sonraki yeni faaliyet gösterecekleri şirketin ismi Fiba Emeklilik ve Hayat A.Ş. olarak değişmiş̧ir.

2017 yılında 2 şirket daha unvanlarını değiştirmiştir, bunlardan biri olan Asya Emeklilik, Bereket Emeklilik ve Hayat A.Ş. olarak, Vakıf Emeklilik de Vakıf Emeklilik ve Hayat A.Ş. olarak faaliyetlerini sürdürmek üzere isim değişikliğine gitmiştir. 
2018 yılında ilk defa Groupama Emeklilik bireysel portföyünü Fiba Emeklilik ve Hayat A.Ş.'ye devretmiş̧ir.

18 Ekim 2019 tarihinde Cumhurbaşkanlığ Kararnamesinde yayımlanan 30922 sayılı Kanunda, Sigortacılık ve Özel Emeklilik Düzenleme ve Denetleme Kurumunun kurulmasına karar verilmiştir (Emeklilik Gözetim Merkezi, 2020, http://www.egm.org.tr/bireysel-emeklilik/tarihce/ ) .

Bireysel Emeklilik Sisteminin Türkiye'de gelişme potansiyeli taşıyan bir müessese olmasının birçok sebebi vardır. Sosyal güvenlik sistemi, geçmişte ve bugün ülkemizde devlete önemli ölçüde mali yük getiren bir yapı olma özelliğini korumaktadır. Tasarruf fonlarının profesyonel şekilde yönetilememesi ve işletilememesi, emekli olma yaşının düşük olması gibi nedenlerle sosyal güvenlik sistemi görevini verimli bir şekilde icra etmekte yeterli olamamıştır. Tüm bu gelişmeler Bireysel Emeklilik Sistemine olan gerekliliği artırmıştır. Bu sistem, sosyal güvenlik sisteminin destekleyicisi olacak ve bu şekilde sosyal güvenlik sisteminin devlete olan maliyeti bir nebze de olsa azalacaktır. 1950'li yıllardan günümüze kadar dünyada birçok finansal kriz yaşanmıştır, bu krizler sosyal güvenlik sistemini de derinden yaralamış ve bu durumdan ülkemiz de yeteri kadar payını almıştır (Arslan, Çelik, \& Haykır, 2018, s. 34).

Ülkemizde yaşanan sorunları sadece küresel krize bağlamak doğru değildir, birçok sebep yeni sisteme ihtiyaç olduğunun sinyallerini vermekteydi. Başlıca sorunlar; nüfustaki yaşlılık oranının artması, sigorta sektörüyle aktüeryal dengenin uyuşmazlık yaşamaya başlaması, kurumsal yönetimde amatörce tavırlar sergilenmesi, ülkemizde sosyal güvenlik sistemin başlıca sorunları olarak ortaya çıkmıştır. 1999 tarihinde reform hareketi başlamış olup bununla birlikte; şirketlerin kurumsal anlamda, finansal yapılarında ve yönetim hususlarında düzenlemeler getirilerek kamusal alanda sosyal güvenlik sisteminin gücüne güç katma beklentisinin yanında, kurumların layıkıyla görevlerini yerine getirerek, yeterli seviyede hizmet verebilmeleri yönünde hedefler belirlenmiştir. Alınan bu reform kararının, bireysel emeklilik konusunda önemli bir unsur olduğu ifade edilmiştir. Ayrıca ülkemiz hukuk devleti olduğundan bu alt yapının da desteğiyle, 28.06.2001 tarihinde "Bireysel Emeklilik Tasarruf ve Yatırım Sistemi Kanunu"nun Türkiye Büyük Millet Meclisi (TBMM) tarafından onaylanarak Resmi Gazetede yayımlanmasıyla 07.10.2001 tarihinde resmen faaliyete geçmiştir (Emeklilik Gözetim Merkezi, 2020, http://www.egm.org.tr/bireysel-emeklilik/tarihce/ ).

Dünyada, bireysel emeklilik sisteminin en önemli avantajlarından bir olan vergi avantajının ülkemizde de uygulanmaya başlamasıyla, yatııımcıların sisteme olan ilgisi artırmıştır. Ücretli çalışan bireyler veya beyanname usulüne göre hizmet veren şirket sahipleri bu avantajdan yaralanabilmektedirler. Sadece bordrolu ve vergi ödeyen şirketler, bu firsattan yararlandığı için sistem üzerinde bazı değişikliklerin yapılması vukuu bulmuştur. Bu amaçla 28338 sayılı Resmi Gazete'de 29.08.2012 tarihinde yayımlanan 6327 sayılı Kanun ile yalnızca vergiler üzerinden kesintilerin uygulamaya alınmasına karar verilmiştir (Kara \& Yıldız, 2016). Bu kesintiler sadece gelir üzerinden yapılmaya başlanmış ve bütün katılımcıların faydalanabilmesi için devlet katkısı sisteme entegre edilmiştir. Bu vesileyle sistem herkes için adil bir yapıya sahip olacak ve uzun süreli fonlama yapılarak ekonomik anlamda rahatlama sağlayacaktır.

Türkiye'de Bakanlar Kurulu kararı ile 01.01.2017 tarihinde yürürlüğe giren otomatik katılımlı BES uygulaması zorunlu olarak 5510 sayılı Sosyal Sigortalar ve Genel Sağlık Sigortası Kanunu'nun dördüncü maddesinin birinci fikrasının (a) ve (c) bentlerine göre 45 yaşın altında Türkiye Cumhuriyeti vatandaşı olan kamu ve özel sektör çalışanlarının tamamını kapsamaktadır. Kırk beş yaşını doldurmuş olanlar ise kendi tercihleri ile otomatik BES dışındaki diğer emeklilik planlarına katılabilmektedirler. (İnneci, 2013). Her ne kadar BES'e giriş kamu ve özel sektör de çalışan 45 yaşın altındaki vatandaşlar için zorunlu olsa da, Sisteme girişten iki ay sonra katılımcılara sistemden çıkış imkanı tanınması tam anlamıyla zorunlu bir uygulama olmadığını göstermektedir.

Devlet katkısı, yatırıma yönlendirilen tutar üzerinden $\% 25$ olarak hesaplanmaktadır. Bu katkı payını alabilmek için katılımcının sistemde en az 10 sene kalması ve 56 yaşını doldurmamış olması şartı vardır. Örneğin, bir katılımcı 45 yaşında olsun devlet katkısını alabilmesi için 10 yıl sistemde kalması yeterli olmayacaktır ikinci şart olan 56 yaş sınırını da doldurmuş olması gerekmektedir. Yani katılımcı 55 yaşına geldiğinde 1 sene daha katkı payı ödeyerek devlet katkısının tamamını almaya hak kazanacaktır. Diğer bir örnekte ise, katılımcı 49 yaşında sisteme girmiş olsun, 56 yaşına geldiğinde yani 7 sene sonra devlet katkısının tamamını almaya hak kazanmış olamayacaktır. Devlet katkısının tamamından faydalanmak için ikinci şartı olan 10 sene sistemde kalması koşulunu yerine getirmesi gerekmektedir. Yani katılımc 3 sene daha sistemde kalırsa devlet katkısının \%25'ini almaya hak kazanacaktır. Sisteme dâhil olan katılımcı 3 sene içerisinde çıkış yapmak isterse devlet katkısından faydalanamayacaktır. 3-6 sene içerisinde ayrılmak isterse devlet katkısının \%15'ini alabilecektir. Yani \%25'in $\% 15$ 'i bu da $\% 3,75$ e denk gelmektedir. 6-10 sene içerisinde ayrılan katılımcı ise $\% 35$ devlet katkısından faydalanabilecektir. Yani devlet katkısının $\% 25$ 'in $\% 35$ 'ini alacaktır. Bu da toplam tasarrufun $\% 8,75$ 'ine denk 
gelmektedir. 56 yaşını doldurmamış ancak sistemde 10 yıl kalan bir kişi ayrılmak istiyorsa birikimin devlet katkısı üzerinden yani \%25'in \%60'ını alabilecektir, bu oran da \% 15 'e denk gelmektedir.

Ülkemizde uygulanan bireysel emeklilik sistemi, sosyal güvenlik sistemini tamamlayıcı niteliğe sahiptir. Bu mantıktan yola çıkarak, 01.01.2017 tarihinde uygulamaya başlayan otomatik katılım sistemi, katılımcıların sistem içerisindeki birikimlerinin yatırım fonlarına yönlendirilerek uzun dönemde daha fazla değer kazanması hedeflenmiştir. Bu durum fon değerlerinin artmasına pozitif katkı sağlamıştır (Meral \& Arıcan, 2020, s. 208).

Otomatik katılım sistemi için özel sektör ya da kamu sektörü farkı etmeksizin çalışan veya çalışmaya başlayacak olan her Türk vatandaşı için ya da mavi karta sahip kişiler için, 45 yaşını doldurmamış fiili ehliyet sahibi kişilere ve bünyesinde 5 kişiden fazla işçi çalıştıran işverenlere 4632 sayılı kanun ile zorunlu hale getirilmiştir. İşveren, asgari olarak işçiye vermiş olduğu brüt maaşın \%3 oranında otomatik katılım sistemine para ayırmak zorundadır. Bu tutar günümüzde 60-TL'nin altında değildir. Sisteme girdikten sonra ayrılma talebi bulunan katılımcılar 2 ay içinde cayma taleplerini bağlı bulundukları emeklilik şirketine bildirerek cayma hakkını kullanabilmektedirler. Ayrılmak istemeyen katılımcılar ise emekli olduklarında yaşamlarını yapmış oldukları bu tasarrufları getirileriyle birlikte alarak yaşam kalitesini artırabileceklerdir. Sistemde kalmak isteyen katılımcılara devletin vermiş olduğu \%25'lik devlet katkısının haricinde, bir kereye mahsus 1.000-TL ekstradan hibe yapılmaktadır.

Türkiye'de yaşayan, fiili ehliyete sahip her birey, bireysel emeklilik sistemine katılabilmektedir. (Can, 2010, s. 140).

Sisteme katılım için emeklilik şirketi ile bir sözleşme yapılması gerekmektedir. Sözleşme içeriğinde katılımcının risk ve getiri durumları belirlenmeli ve katılımcının fon dağılım oranları seçilmelidir. Bireysel emeklilik sözleşmesine ulaşmak isteyen katılımcı, plan içeriğinde bulunan fonları, katkı pay oranlarını, yapılacak olan kesintileri okuyarak giriş bilgi formunu da doğru şekilde doldurmak şartıyla teklif formunu düzenleyip imzalayarak sisteme dahil olabilecektir. Sözleşmenin geçerli sayılabilmesi için sözleşmenin imzalanan tarihten 30 gün sonuna kadar herhangi bir sebepten dolayı çıkışının yapılmaması gerekmektedir. Katılımcı, bireysel emeklilik sözleşmesini 30 gün içerisinde fesih etme hakkına sahiptir. Giriş aidatı ve diğer kesintiler dahil olmak üzere hiçbir kesinti yapılmadan, hatta bu süre zarfında fon getirisi olmuş ise getiri ile birlikte cayma hakkını kullanan katılımciya iade edilecektir.

\section{Dünya'da Bireysel Emeklilik Sisteminin Gelişimi}

Ülkemizde tam anlamıyla 7 Ekim 2001 yılında yürürlüğe giren bireysel emeklilik sisteminin, dünya genelinde çok daha geçmişe uzandığını söylememiz mümkündür. Bismarkyan sistemi olarak bilinen ve sistemin kurucusu olan Prusya Şansölyesi Otto Van Bismark, 1881 tarihinde yoksul halka varlıklı kesimler tarafindan destek olması amacıyla günümüzdeki bireysel emeklilik sistemi mantığındaki sistemi bulmuştur.

Ülkemizde karşılaştığımız sosyal güvenlik sisteminin yetersiz kaldığı alanlar, dünya genelinde de benzerlik göstermektedir. Dünya genelinde ekonomik anlamda desteklenmeye çalışılan sosyal güvenlik sisteminin, yaş ortalamasının artması, demografik değişiklikler, aile içerisinde oluşan değişiklikler, sağlık alanındaki giderlerin artış göstermesi, fonların verimsiz kullanılması, iş olanaklarının azalması, vergilerin yüksek oluşu gibi olumsuz etkileri saptanmıştır (Yemez \& Akdoğan, 2019, s. 107). Bu olumsuz etkilerin ortaya çıkması, emekli maaş ödemelerinde zorluk yaşanmaya başlamasına sebep olmuş ve bireylerin emekli olabilme yaşları artmıştır. Bu durum dünya genelinde yeni bir sistemin mutlak suretle bulunması gerektiği gerçeğini ortaya koymuştur.

Bireysel emeklilik sistemi bazı ülkelerde zorunlu hale getirilse de, birçok ülkede gönüllülük esasına dayandırılmıştır. Vatandaşlarını zorunlu olarak sisteme dâhil eden ülkelerin başlıcaları: Bolivya, Meksika, Şili ve Uruguay'dır. 20 üyesi bulunan Organisation for Economic Co-operation and Development (OECD) ülkeleri ABD, Kanada, Belçika, Avusturya, Fransa, İtalya, İsviçre, Hollanda, İspanya, Lüksemburg, Portekiz, Almanya, İrlanda, Norveç, İzlanda, İngiltere, İsveç, Danimarka, Yunanistan ve Türkiye’yi kapsamakta olup, bu ülkelerde sisteme katılım zorunlu değildir (Arslan, Çelik, \& Haykır, 2018, s. 29).

\section{G7 Ülkelerinde Uygulanan Bireysel Emeklilik Sistemi}

G7 ülkeleri Almanya, Birleşik Krallık, ABD, Kanada, Fransa, Japonya ve İtalya'nın içerisinde bulunduğu yedi ülkeden oluşmaktadır (Wikipedi, 2020, G7 Ülkeleri). Avrupa Birliği de G7 ülkeleri içine dahil edilmektedir. Bu çalışmada G7 ülkelerinde uygulanan BES'e değinilecektir. 


\subsection{Almanya'da Bireysel Emeklilik Sistemini Uygulamaları}

Almanya, emeklilik sigorta sisteminin ve modern anlamda sosyal güvenlik sisteminin ortak sentezini yaparak, İngiltere'de de uygulanan sistemden faydalanarak sosyal devlet yapısının oluşumuna öncülük eden ilk ülkedir. Almanya'da bireysel emeklilik sisteminin işlemeye başlaması 1981 yılına uzanmaktadır. Bu yılda çıkan kanun ile ulusal anlamda ilk emeklilik sistemi ile malullük ve yaşlılık sigortası kavramları ortaya çıkmıştır.

Almanya'da ortaya çıkan bu sistem kısa zamanda Avrupa'ya yayılmaya başlamıştır ve sistemden maksimum seviyede fayda sağlanmaya başlanmıştır. 1930 yılına gelindiğinde ise Kanada ve ABD'de sistem bütün fonksiyonlarıyla kullanılmaya başlamıştır. 1940 senesinde ölüm, maluliyet ve yaşlılık sigortası 33 ülkede uygulanmaya alınmış, 1995 senesine gelindiğinde ise bu uygulamayı 158 ülke kullanır hale gelmiştir. Tüm anayasalarda 'Atlantik Şartı' konulmuş ve bu sebeple bütün bireylerin sosyal güvenlik ve emeklilik hakkından faydalanması sağlanmıştır. 2001 yılında Almanya'da emeklilik reformu ortaya çıkmış ve bu reform ile 3 aşamalı bir yapı gündeme gelmiştir. Bu aşamalar; sosyal sigortalar arası denge, mesleki hazırlık planları ve özel emeklilik sigortasıdır (Arslan, Çelik, \& Haykır, 2018, s. 34). Ortaya çıkan bu emeklilik sistemi ilk başlarda zorunlu olsa da çok fazla eleştiri alması sebebiyle gönüllü şekilde değiştirilmiştir.

\subsection{Birleşik Krallık’da Bireysel Emeklilik Sisteminin Uygulamaları}

Sosyal sigorta sistemi dişında mesleki sigortalarla özel sigortalara yönelik bir birikim için teşvik paketleri çıkartılmıştır. 1986'dan önce, ulusal sigortadaki işçi prim ve işveren paylarının; işveren tarafından belirlenerek asgari aylı garantili bir sistem oluşturulması ve ulusal sigorta sisteminden para iadesi gerçekleştirilebilecekti. 1986 tarihinden sonra çıkan yasa ile aynı para aktarım yöntemi devam ettirilmişti, ancak Nisan 1988 ile Nisan 1993 seneleri içerisinde, SERPS haricinde başka bir bireysel emeklilik sistemine giriş yapmış herkese, yüzde iki oranında ekstradan ulusal sigorta sisteminden para iadesi de yapılmıştır. Bunun dışında mesleki sigortaya bağlı üyelerin de yapmış oldukları birikimlerinin de doğrudan transfer etmek şartıyla bireysel emeklilik sistemine dahil olmaları kolaylaştırılmıştır. Bu sayede emekli olmaya hak kazanamadan işten ayrılan ve işverenlerince yürütülen mesleki sigortası kesintiye uğrayacak kimselerin bu durum karşısında mağdur olmamaları için 1973 tarihinde yeni bir yasa çıkartılarak adil bir çözüm ortaya konmuştur. Buradan da anlaşılacağı gibi, yasa taslağında belirlendiği gibi SERPS sistemi tam anlamıyla ortadan kaldırılmasa da; yapılan bu detaylı değişiklikler ile SERPS sisteminin yerine devlet dışı sigorta sistemlerine yönelmesine ilişkin teşvikler ortaya çıkmış ve sigortalılarda özel sigorta sistemine doğru bir geçiş gözlemlenmiştir. Böylelikle 1988 reformlarından sonra temel emeklilik sistemi haricinde kişilerin tercihleri arasında SERPS ve işverenin koordine ettiği mesleki emeklilik planları haricinde başka bir bireysel emeklilik sistemi de eklenmiştir. Sosyal güvenlik sisteminin özelleştirilmesi için bu zamana kadar ki en önemli adımların atıldığı sonucuna varılmıştır.

İkinci Devlet Emekli Maaşı (S2P), SERPS'nin yerini almak üzere 6 Nisan 2002 tarihinde İngiltere'de İşçi Partisi Hükümeti tarafından başlatılmıştır. Bu değişikliğin temel amacı, düşük ve 1lımlı kazananlar lehine, daha yüksek kazananlar hesabına mevcut Ek Emeklilik (AP) avantajlarını artırmak ve belirli bakıcılar ile uzun süreli hastalığı veya sakatlığı olan kişileri sisteme ilk kez dahil etmek için erişimi genişletmekti.

\subsection{Amerika Birleşik Devletlerinde Bireysel Emeklilik Sisteminin Uygulamaları}

Amerika Birleşik Devletlerinde bireysel emeklilik sistemi alışılmışın dışında karmaşıklıklarla dolu bir sistem olarak hayata geçmiştir. Sosyal sigortalar programının en önemli tamamlayıcı unsurlarından biri olan BES, Amerika' da çok önemli bir konuma gelmiştir. Kanunun yönettiği sosyal güvenlik sistemi, ulusal vergi sisteminden elde edilen gelir ile kaynak oluşumu sağlamaktadır. Bu durum da belirli bir süre sonra olumsuzlukları beraberinde getirmiştir.

BES'in amacı yoksulluk sınırı içerisindeki bireylere en üst düzeyde fayda sağlamaktır. Bunu yaparken yaşam süreçleri içerisinde kazançlarının bir kısmının tasarrufa yönlendirilmesi hususunda açıklayıcı bir program geliştirilmiştir. BES tamamıyla gönüllülük esasına dayandırılırken, sadece iş yeri sahiplerinin destekleri ile çalışmaktadır. ABD'de iki çeşit emeklilik planına rastlanmaktadır: Birincisi tek bir işveren ya da kurum tarafından desteklenen ve idare edilen planlar, ikincisi ise çok işverenli planlar olarak bilinen yaygın endüstri şirketleri çalışanlarını kapsayan planlardır (Tapia, 2008, s. 79).

1974 senesinde ABD’de çalışanlar için emekli olduklarında alacakları aylık gelirleri için Emekli Garanti Kanunu çıkarılmıştır. Bu kanun ile bireylerin çalıştıkları şirketin iflas etmesi neticesinde, plan dahilinde olan katılımcıların emekli aylıklarının kaybetme riskleri ortadan kalkmıştır. Bu kanun ile bireyler sisteme dahil olmak için gerekli aksiyonları almaya başlamışlardır(Arslan, Çelik, \& Haykır, 2018, s. 32). 
ABD'de katkı paylı planlar için mutlaka bireylerin; hayat sigorta şirketleri, banka, yetkili finans kuruluşu veya portföy şirketleri tarafından açılmış olan hesaplar aracıllı̆ıyla kar paylarını almaları sağlanabilecektir. Bu planın avantajlarını ise şu şekilde sıralayabiliriz; ilk avantajı, bu planda tahsil edilen ödemelerin o yıl içindeki gelir vergisinden düşülebilecek olmasıdır. Bir diğer avantajının da tasarruf yapılan tutardan kazanılan paranın herhangi bir faiz, temettüye konu olmaması ve buradaki paraya ihtiyaç duyulacağı zamana kadar beklemesinden dolayı vergi yansitılmamasidır.

\subsection{Kanada'da Bireysel Emeklilik Sistemin Uygulamaları}

Kanada'da diğer ülkelerde uygulanan 3 basamaklı emeklilik sistemi mevcuttur. Sistemin 1. basamak, devlet kontrolünde bulunan sosyal güvenlik sistemi, 2. basamak, mesleki emeklilik planları, 3. basamak ise kayıt altındaki emeklilik tasarruf planlarını kapsamaktadır. Kanada'da bulunan bireyler, emekli olmadan önce kazançlarının bir miktarıyla emekli olduklarında ek gelir elde etmekte ve tescilli olan bu emeklilik tasarruf programları için vergi muafiyeti sağlamaktadırlar.

Kanada'da bulunan bireysel emeklilik planları, bireylerin emekli olduklarında gelir sağlamak için önemli bir tamamlayıcı unsurdur. 1800'lü yıllarda ilk olarak bu sistem ortaya çıkmıştır. Bu emeklilik planı, 1917 senesinden itibaren, vergi muafiyet ve uygulanarak desteklenmiş̧ir. 1957 senesinde ilk olarak gönüllülük esasına dayanan bireysel emeklilik planları ortaya çıkmıştır. Kanada'daki emeklilik sistemleri, bireysel emeklilik sistemi ve mesleki emeklilik sistemi ile 65 yaş üzerinde bulunan bireylere temel gelir desteği sağlayan ve zorunlu olarak yapılan kamu emeklilik sistemidir. İşçi statüsünde olan veya normal çalışan bireyler temel emeklilik hizmeti için gelirlerinin belirli oranlarında bu sisteme destek vererek tasarruf yapmaktadır. Ayrıca kamuda çalışan memurlar ile tüm bireyler bu sistem tarafından desteklenmektedir. Mesleki emeklilik sistemi ise sadece iş yeri sahipleri tarafından destek verilen planlardan oluşmaktadır. Tescillenmiş emeklilik birikim programlarının içeriğinde katılımcıların vergi muafiyetlerini de sağlaması bulunmaktadır. Son olarak ortaya çıkan bireysel emeklilik planın amacı, kayıtlı emeklilik ve tasarruf planlarını kapsayarak bireylerin vergi teşvikleriyle düzenli şekilde birikim yapmalarını sağlamaktır. Bu sistem, yatırım fonu şirketleri, bankalar, sigorta şirketleri ve aracı kurumların bulunduğu birden çok finans kuruluşu aracılığıyla kurulmakta ve yönetilebilmektedir (Arslan, Çelik, \& Haykır, 2018, s. 33).

\subsection{Fransa'da Bireysel Emeklilik Sistemi Uygulamaları}

1980 senesinden itibaren Fransa'da yürürlükte olan emeklilik sisteminin değişimi yönünde baskılar artmıştır. Bu bağlamda Fransa'da 4 adet değişim planı uygulanmaya başlanmıştır. Bunlardan 1995 senesinde Juppé Planı, 1997 senesinde Thomas Kanunu ile emeklilik birikim planları ve emeklilik birikim fonları sistemi ortaya çıkmış olsa da bu kanun olumlu sonuçların ortaya çıkmasını sağlayamamıştır. 1993 senesinde ortaya çıkan Balladur ile 2003 senesinde ortaya çıkan Ratfarin reformlarında başarıya ulaşıılmışıı. Fransa'da uygulanan emeklilik sistemindeki karmaşık yapı ABD'yi anımsatmaktadır. Emeklilik sistemi birden çok basamağı bünyesinde barındırmakta olup 1. Basamağını 2 kat oluşturmaktadır. Caisse Nationale d'Assurance Vieillesse(CNV)-Fransız Ulusal Emeklilik Fonu, kamu emeklilik sisteminin birinci basamağını oluşturup birinci katında yerini belirlemekte ve dağıtım sistemi olarak, belirli bir dönemde ödenmesi gereken sosyal güvenlik harcamalarının aynı dönem içerisinde elde edilen gelirler ile karşılanması esası olan (pay-as-you-go-PAYGO) uygulamaktadır(Blake,D., 2000, s. F47). Bu sistemde birikimler bireylerin gelirleriyle doğru orantıda gerçekleşmektedir. İşşilerin ve işverenlerin sisteme girmeleri zorunludur. Maden çalışanları, demiryolu işçileri, tarım çalışanları, kamuda çalışanlar gibi 16 tane meslek grubu bulunmaktadır ve her bir meslek grubu için ayrı birikim planları bulunmaktadır. Ülkedeki emeklilik sisteminde bu kadar çok grup olsa da çalı̧̧an bireyler 4 farklı kategoride toplanmıştır. 1. grup \%65 i oluşturan özel sektör çalışanlarıdır. Regimé general emeklilik planları özel sektör çalışanları için hazırlanmıştır. 2. grup ise \%20 ile kamu çalışanlarını barındırır ve bu grup için de Regimé spéciause emeklilik planı hazırlanmıştır. 3. grup \%3'lük oranı ile tarım çalışanlarını kapsamakta olup bu grup için de Regimé agricole emeklilik planları hazırlanmıştır. 4.grup içinde \%12'lik iş gücüne sahip maaş almadan çalışanlar ile serbest meslek sahibi olanlar bulunmaktadır (Bayrak Salantur, 2015, s. 61).

1. basamağın 2. katı zorunlu olup bu katta PAYGO (pay-as-you-go) sistemine katkı sağlayan unsurlar yer almaktadır. 1947 tarihinde işveren ile işçi sendikalarını kapsayan ARRCO (Association des Régimes de Retraites Complémentaires), üst düzeyde görevlere sahip beyaz yakalı çalışanları kapsayan AGIRC (Association Générale des Institutions des Retraites des Cadres) sistemleri uygulanmaktadır. ARRCO ve AGIRC sistemleri için amaçlarının kar olmadığı söylenebilmekte ve bunların birikim tutarları bireylerin gelirlerine orantılı şekilde 
yapılmakta ayrıca prim ödemelerinde alt ve üst limit bulunmakta ve CNV tarafindan denetlenmektedir. Bu sistemin 2. basamağını gönüllü katılım ile ilgili olup fonlama mantığına dayanmaktadır. Yine bu basamakta küçük ve orta büyüklükteki işletmelerin yöneticileri ile birçok sigorta sözleşmesi yapılmakta, yapılan bu sözleşmelerde az sayıda bulunan şirketlere ait fonlar da değerlendirilmekte, bunların katkı birikim tutarları farklılık göstermektedir. 2004 senesinde son olarak bireysel emeklilik planları adı altında 3. basamak oluşturulmuştur. Fransa'da genellikle hayat sigortaları, bireysel emeklilik planları şeklinde yapılmaktadır. 2004 senesinde yeni bir düzenleme yapılarak portföy yönetim firmaları ile bankalar bireysel emeklilik fonlarını sistemde uygulamaya başlamıştır. Emeklilik birikim fonlarının oluşumu, BES planlarının ortaya çıkmasıyla gerçekleşmiştir (Bayrak Salantur, 2015, s. 61).

\subsection{Japonya'da Bireysel Emeklilik Sistemi Uygulamaları}

Japonya'da emeklilik sistemi üç basamaklı olarak gerçekleşmektedir. 1. basamak ulusal temel emeklilik planı, 2. basamak çalışan emeklik sigortasıdır. Bu 2 basamaktaki planlar devlete ait olup sisteme giriş zorunluluğu bulunmakta ve emeklilikte gelir elde etmeyi amaçlamaktadır. Bu planlarda biriken fonları devlet farklı yatırım araçlarına yönlendirerek değerlendirmektedir. 3. Basamakta bulunan plan tümüyle katılımın gönüllülük esasına dayalı olduğu ve devletten bağımsız olan emeklilik planlarını içermektedir.

İşyeri sahipleri, işsizler, çiftçiler ve öğrenciler için ulusal emeklilik fonu bu meslek gruplarını kapsamaktadır. 2059 yaş arasında bulunan bireyler bu sisteme dahil olmaktadır. Bu planda birikimlerde sabit düzeyde prim tahsil edilmekte ve sabit düzeyde aylık maaş şeklinde verilmektedir. Emekli aylığını tam alınabilmesi için kesintisiz 25 sene prim ödenmesi yapılması gerekmektedir. 1986 senesinde yapılan reform sonucunda tam emekli maaşı alınabilmesi için gerekli bulunan süre 40 seneye çıkartılmıştır. Japonya'da emeklilik yaşı erkek ve kadınlarda 65 olarak uygulanmaktadır. Ancak verilecek aylık maaşın düşük olmasının kabul edilmesi halinde 60 yaş sonrasında da erken emeklilik firsatı bulunmaktadır. Emeklilik sistemine dahil olarak çalışan bireylerin bakmakla yükümlü oldukları kişiler bir ilave prim ödemesi yapmadan direkt olarak ulusal emeklilik sistemi içerisine dahil edilmektedir. Ulusal emeklilik sistemindeki ödemelerin 1/3'ü devlet bütçesinden karşılanmaktadır. Emekli maaşları her yılın nisan ayında tüketici fiyat indeksi göz önüne alınarak yeniden belirlenmektedir. 2. basamak emeklilik sistemi emeklilik için gelir elde etmeyi amaçlamakta ve bu sisteme katılım zorunlu tutulmakta, ayrıca bu basamak kazançla ilişkili olup devlet tarafından yönetilmektedir.

3. basamak ise devletten bağımsız bir şekilde ilerlemekte, katılım tam anlamıyla gönüllük esasına dayanan emeklilik planları şeklinde olmaktadır. Bu planda bireyin emekli olunduğunda düzenli bir gelir elde etmesi amaçlanmış ve ileri derecede gelişmiş fonlama teknikleri kullanılmıştır. Japonya'da çalışanların ortalama \%90’1 3.basamak planlara sahiptir. İşten ayrılan bireylerin tazminat planları ise işveren ile çalışanlar arasında yapılan bireysel iş sözleşmesi veya toplu iş sözleşmelerinde belirtilmektedir. Bu düzenleme, çalışanların işyerlerinden kendi istekleri ile (istifa etme) ya da kendi istekleri dışında ayrılması (ölüm, işten çıkarılma, normal emeklilik yaşına gelme) durumlarında çalışan bireylere yapılan ve genellikle tek bir seferde toplu olarak ödenen tazminatı karşılamak için getirilmiştir (T \& T Sigorta Bireysel Emeklilik, 2020, https://www.ttemeklilik.com/dunyadakibireysel-emeklilik-sistemleri.html).

\section{7.İtalya'da Bireysel Emeklilik Sisteminin Uygulamaları}

İtalya uygulanan sosyal güvenlik sistemi de diğer ülkelerdeki uygulamalar gibi 3 basamaklıdır. Sistemin 1. basamağında zorunlu devlet güvencesini barındıran programa yer verilmiştir. Ülkedeki Emeklilik yasası dağıtım esaslı olup işçi ve işveren için zorunludur. 31.12.1995 yılından öncesi için 18 seneden uzun zaman sistemde tasarruf yapanlarla, 2001 senesinden sonra erkekler için 65, bayanlar için de 60 yaş sınırında olanlar, 20 sene tasarruf yaparak sisteme dahil olduklarında devletten emekli olabilmektedirler. Ülkede 70 yaşını doldurmuş herkese yaşlılık yardımı yapılmaktadır. 2002 yılı itibariyle 35 yıl prim ödeyip 57 yaşında olanlar ile 38,7 sene prim ödeyenler yaşları ne olursa olsun emekli olabilmektedirler

2. ve 3. basamakta bulunan mesleki ve bireysel emeklilik sisteminde devlet tarafından ortaya konulmuş garantiden bahsedilemez. Bazı emeklilik planları, belli bir iş yerine bağlı olmadan üretim yapan bireyler için uygulanmakta ve bu planlar genellikle bireylerin isteklerine bağlı olarak yapılmaktadır. Bazı katkı planları, işçilerin isteğine bağlı yani gönüllülük esasına dayalı, bazı katkı planları ise işçilerin, işverenle yaptığı sözleşmeye dayalı olarak ortaya çıkmıştır. 2. basamakta mesleki emeklilik programlarına yer verilmiştir. Kamu emeklilik sistemindeki emeklilik yaşı sabit tutulmuştur. Emeklilik zamanı gelen bireylerin, sosyal güvenlik sistemindeki gibi kadınlar için yaş 60 , erkekler için ise yaş 65 olacak şekilde planlanmıştır. Ayrıca bu kişilerin en az 5 sene prim ödeyerek sistemde bulunması şartı getirilmiştir. Sistemde 8 yıl ödeme yapan bireyler sağlık harcamaları, ev sahibi olma, mesken tadilatlarında yapacakları yenilikler için sistemdeki tasarruflarını kullanabilmektedirler. Ödemesi yapılmış olan 
primlerden belli oranlarda vergiden indirim yapılabilmektedir. 3. basamak emeklilikte bireysel veya grup hayat sigortaları yer almakta ve bunlar sigorta şirketleri tarafından idare edilmektedir. Emekli olma yaşı önceki basamakta bulunan yaș sınırlamalarıyla benzerlik göstermektedir. Bu basamakta 15 sene sistemde bulunmak şartıyla, 10 sene daha erken emekli olma fırsatı ortaya çıkmıştır. Bireysel emeklilik fonlarının mutlak suretle banka, brokerlik firması veya sigorta şirketi gibi finansal kurumlar tarafından yönetilmesi zorunluluğu bulunmaktadır. Bu basamakta finansman yapısı tümüyle fonlama esasına dayanmaktadır. Fonlarda herhangi bir devlet garantisinden söz edilememektedir. Bireylerin sisteme katılımı isteğe bağlı olup, bireylerin tercihine sunulmuştur. Sözleşme süresi dolan bireylerin, getirileri ile birlikte tasarruflarının yarısını peşin olarak, diğer yarısını ise mutlak suretle maaş olarak almak zorunlulukları bulunmaktadır (T \& T Sigorta Bireysel Emeklilik, 2020, https://www.ttemeklilik.com/dunyadaki-bireysel-emeklilik-sistemleri.html ).

Tablo:1 Katılımcıların Sisteme Giriş Yaşı

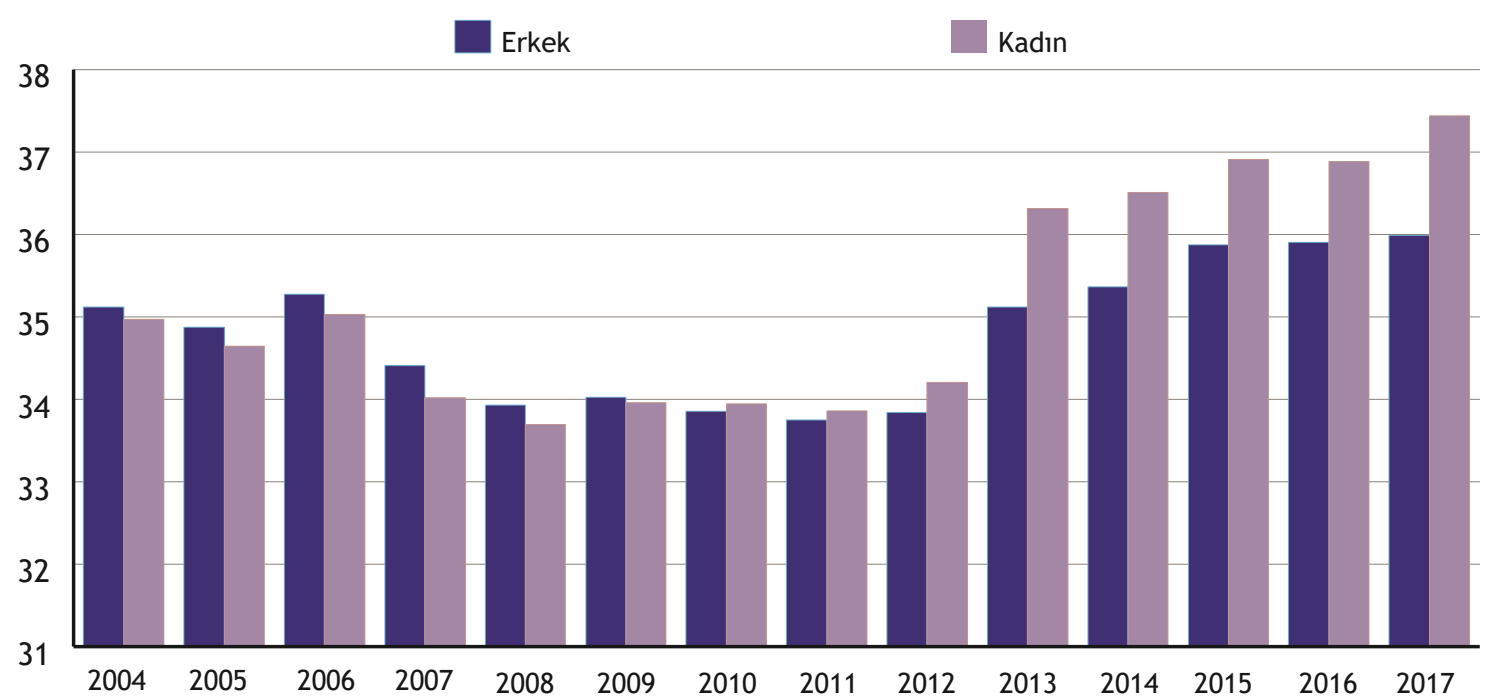

Kaynak: Emeklilik Gözetim Merkezi (Emeklilik Sistemi Gelişim Raporu, 2017, s. 34)

Tablo 1'de katılımcıların sisteme ilk defa giriş yapan erkek ve kadın bireylerin yaşları ve sisteme girdikleri yıllar detaylı şekilde incelenmiştir. Sisteme ilk kez dahil olan bireylerin yaş ortalaması 35,3 olduğu görülmektedir. Daha sonraki yıllarda bu yaş sınırının düştüğü, 2011 yılında erkek katılımıı yaşının 33,8 kadın yaşının ise 33,9 olduğu görülmekteyken, 2012 yılından sonra yaş sınırının giderek arttığını 2017 yılında ise erkeklerin 36 yaşına, kadınlarda ise 37,5 yaşına çıktığı gözlemlenmektedir. Tablo 1'de katılımcıların sisteme dahil iken yapmış oldukları birden çok katılım taleplerinde, sadece sisteme ilk defa dahil oldukları tarihte bulundukları yaş göz önünde tutulmuştur.

Tablo 2. Sözleşmelerin Sisteme Dahil Oluşunun Yıllara Göre Dağılımı

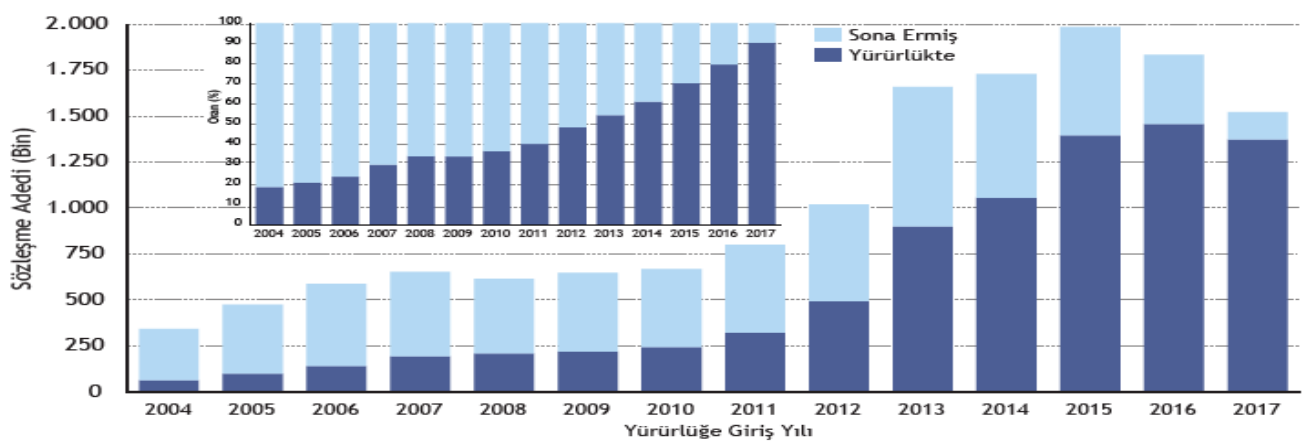

Kaynak: Emeklilik Gözetim Merkezi (Emeklilik Sistemi Gelişim Raporu, 2017, s. 24)

Tablo 2'de sözleşmenin yürürlüğe girdiği adetlerin, yıllara göre dağılımı incelendiğinde ilk dönemlerde sona eren sözleşmelerin fazlalığı göze çarpmaktadır. Tablodaki sözleşmelerin sona erme şekilleri (fesih, yürürlükten sonra cayma, başka bir şirkete aktarım yapma, vefat/maluliyet, emeklilik, hesapların bir sözleşmede toplanması, katılımcının kendi istekleri ile ayrılmaları) ile son bulan sözleşme adetlerinin belirlenmesi incelenmiştir. 
Bireysel Emeklilik Sisteminin 2004 yılında sisteme giren sözleşmelerin \%10'nun yürürlükte kaldığı, \%90’ın da sona erdiği dikkat çekmektedir, daha sonraki yıllarda yürürlükteki sözleşmelerin arttığ ve sona eren sözleşme adetinin de düştüğü görülmektedir. 2012 yılında Bireysel Emeklilik Sisteminin önemi vurgulandıkça bu oranın \%50 seviyelerine doğru arttığı gözlemlenmektedir. 2017 yılı oranları incelendiğinde yürürlükteki sözleşme adetinin \%90’lı seviyelere çıtı̆̆ 1 ve sona eren sözleşme adetinin de \%10 seviyelerine gerilediği göze çarpmaktadır.

Tablo 3. Sözleşmede kaldıkları zamana (Kıdem) Göre ve Toplam Fon Tutarı (TL)

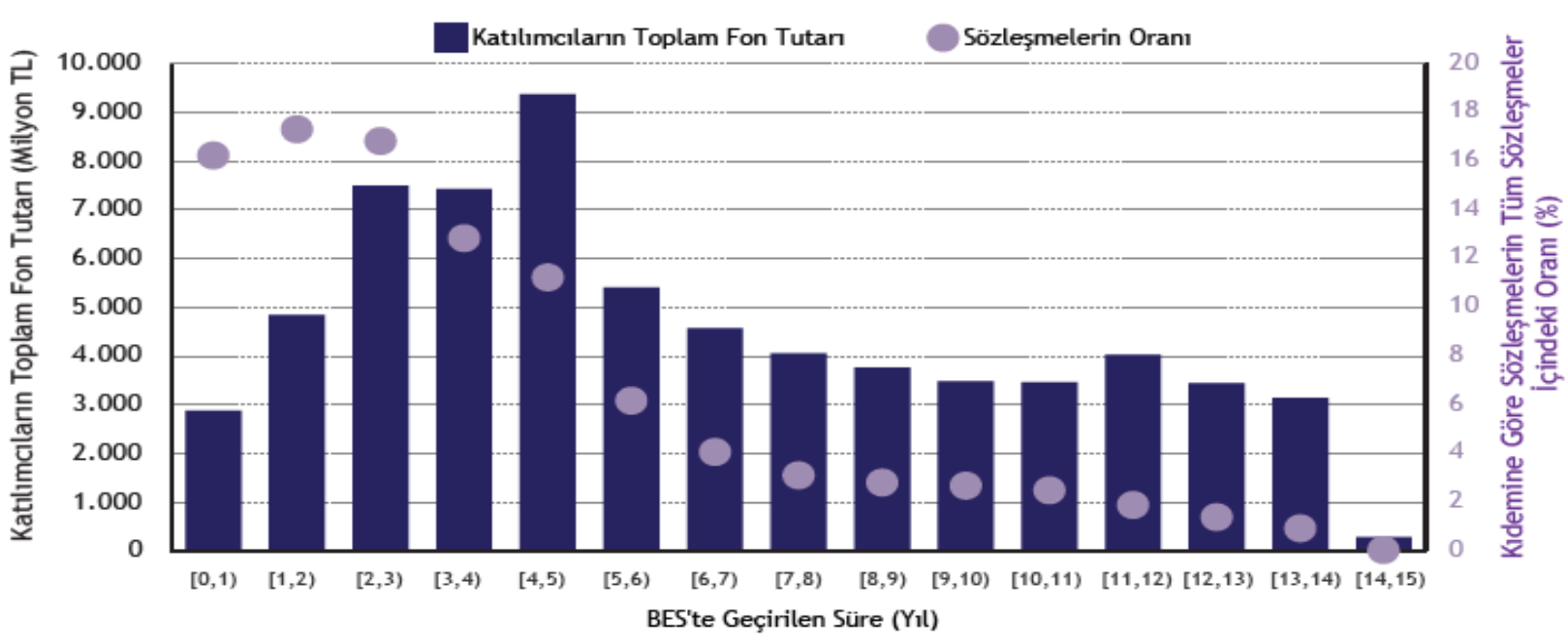

Kaynak: Emeklilik Gözetim Merkezi (Emeklilik Sistemi Gelişim Raporu, 2017, s. 23)

Sistemde geçirdikleri süreye göre sözleşme ve fon tutarları incelendiğinde, sözleşme oranı $(0,1)$ sistemde kalan sözleşme fon tutarının 2.900 milyon TL iken, (4,5) yıl sistemde kalan katılımcıların fon tutarının 9.300 milyon TL olduğu gözlemlenmektedir. Daha sonraki senelerde ise fon tutarlarının azaldığı ve sistemde $(14,15)$ yıl kalan katılımcıların fon tutarının 200 milyon TL civarında olduğu görülmektedir.

Bunun yanı sıra kıdeme göre sözleşmelerin tüm sözleşmeler içindeki oranının da $(0,1)$ yıl sistemde kalan oranının $\% 16,5(1,2)$ yıl sitemde kalanlarının oranının \%17,5 ve daha sonraki yıllarda bu oranın hızla azaldığ dikkat çekmektedir. Sistemde $(14,15)$ yıl kalanların oranı ise \%0,10 seviyelerine gerilemiş olduğu gözlemlenmiştir. 2017 yılsonu itibarı ile katılımcıların emeklilik yatırım fonlarındaki büyüklüğü 67.677.308.661 TL ulaşmış ve sistemdeki sözleşmelerin tamamlandığı yıl detayında incelenmiştir (Emeklilik Gözetim Merkezi, Emeklilik Sistemi Gelişim Raporu , 2017, s. 23).

\section{Swot Analizi}

Çalışmamızda swot analiz yöntemi kullanılarak sistemin, güçlü yönleri, zayıf yönleri, tehditleri ve firsatları maddeler halinde gösterilecektir.

Tablo 4. Bireysel Emeklilik Sistemine İlişkin SWOT analizi

\section{GÜÇLÜ YÖNLER (STRENGTHS)}

Sistemin anlaşılır bir yapıya sahip olması

Uygulanacak mevzuatın detaylı belirlenmesi için sistemin devamlı gelişimine yönelik özelliklerin ve beklentilerin ön planda olması

$>$ BES'teki en önemli faydalardan biri, vergilerde uygulanan indirimlerin olması

$>$ Sisteme giriş yapan bütün bireyler belirlenen şatları yerine getirdiklerinde devlet katkısından istifade edebilecek olmas1
Yapılan her birikimin Türkiye'nin makroekonomik denge ve oranlarını artıracak olması

Ülkemizin tasarruf oranlarının artmasıyla risk primlerinin düşeceği anlamına gelmesi

Kıymetli maden fonlarına yönelmek ve değişik portföy yapısına sahip fonların kurulmasına olanak tanınması da sektörün gelişmesini sağlamıştır.

Emeklilik Fonlarına kayıtlı olanların çoğunluğunun alt ve orta gelir grubunda oldukları düşünülürse, bu 
durumun sistemin hedeflerini gerçekleştirip güçlü kıldığı söylenebilir (İşseveroğlu \& Hatunoğlu, 2012, s. 165).

$>$ Ülkemizde geçmişi uzun yıllara dayanan bireysel emeklilik firmalarında yabanci sermayesi olan şirketlerin bulunması ürün, pazarlama, operasyon ve organizasyon yapısını öğrenmemizi sağlamaktadır.

> Oluşturulacak fonların özelleştirmesi ile birlikte sermayenin tabana yayılması sağlanacak bununla birlikte gelir dağılımındaki adaletin tesis edilmesi başarılı bir şekilde ortaya konmuş olacaktır.

\section{FIRSATLAR (OPPORTUNITIES)}

> 2002 senesinde TUIK' in yaptığı çalışmada, 3.492 USD olan kişi başına düşen gelir seviyesinin seneler içerisinde yukarı yönlü bir artışın eğilimi gösterilmiş ve 2010 senesinde 10.067 USD seviyesine yükselmiştir.

2012-2014 y1lları için Kalkınma Bakanlığının düzenlediği orta vadeli program içinde 2011 Ekim raporu dikkate alınarak ortaya konan projeksiyonlar, ülkemizin 2014 senesinde birey başına düşen gayri safi yurtiçi hâsılanın 12.412 USD'ye artacağı yönündedir (İşseveroğlu \& Hatunoğlu, 2012, s. 172).

> Türkiye'de sigorta anlayışının eksik olması sebebiyle, ülkemizde bireysel emeklilik sisteminin yıllık büyümesi $\% 1$ oranındadır.

> Uzun dönemli bir yatırım aracı olması,

$>$ Devlet katkısının tamamını alabilmek için 56 yaş ve 10 yıl sistemde kalma zorunluluğunun bulunması

> Sistemin gelişmesini engelleyen faktörler; Ülkemizde yaşanan finansal krizlerden dolayı sisteme güvenin tam olmaması, kişi başına düşen milli gelirin az olması, zorunlu devlet güvenlik sisteminin var olması

> Sisteme katılan yatırımcıların yapmış oldukları küçük birikimlerin hisse senetlerine yönlendirilerek değerlendirilmesi sistemin önünün açık olduğunu ortaya koymaktadir.

$>$ Asgari getiri garantisinin bulunmaması erken yaşta sisteme dahil olan katılımciların uzun seneler sistemde kalma zorunluluğu, emeklilik programındaki birikimlerin finansal piyasalardaki dalgalanmalardan ortaya çıkacak riskinin tamamen birikim yapan yatırımcılara yüklenmesi gerçeği sistemin güvenilirliğini engellediği gibi bireylerin sistemden çıkış yapmalarına da yol açabilmektedir.

$>$ Vakıf ve sandıklar tarafından değerlendirilen toplanan primlerin, fazla sayıda yasal düzenlemesi bulunan BES'i olumsuz yönde etkiyecektir. Bu
Gayri safi yurtiçi hâsılanın artması bireysel emeklilik sistemi için firsattır.

BES'te emeklilik gelirlerinin vergi dışında olması ile ilgili yapılan çalışmalar emeklilik planlarına iştiraki artırmas1

Sistemde sağlanan vergi teşvikide katılımcı sayısını artırmaktadır.

$>$ Vergi teşviki ve emeklilik gelirlerinin vergi dışında tutulmasiyla en önemli firsat da emeklilik portföylerinin büyümesi, kalkınmanın hızlanması ve işsizliğin öne geçilmesi ve buna benzer olumlu etkilerinin olması zaman içinde vergi gelirinde oluşacak artışı tetikleyecektir.

$>$ Çalışan bireyler için kıdem fonunun oluşturulmasıyla ve oluşturulan fonun BES içerisinde değer kazanmasıyla birlikte sistemde fonun büyüklüğü artış gösterecek, sistem içerisindeki şirketlerin gelirleri artacaktır.

ZAYIF YÖNLER (WEAKNESSES)

\section{TEHDITLER (THREATS)}

durum sektörde olan ve sektöre girmek isteyecek yabanc1 yatırımcilara olumsuz yansiyacak ve ülkemize olan güvenlerini zedeleyecektir.

Menkul kıymetlerde değerlendirmesi öngörülen uzun vadeli emeklilik fonları, ülkemizde rekabet ortamının çok olması menkul kıymetlerin getirileri kısa vadeye odaklanmış ve böylelikle temel işlevlerinden uzaklaşmasına sebep olmuştur.

Emeklilik şirketlerinin en önemli gelir kalemlerinden biri yönetim gider kesintisidir. Bunun gibi gider kalemlerine yönetim tarafından sınır getirilmesi ve oranlarının düşürülmesi emeklilik şirketlerini finansal anlamda zora sokacaktır 


\section{SONUÇ}

28 Mart 2001 tarihinde TBMM tarafindan kurulan komisyon ile günümüze kadar uygulanmakta olan bireysel emeklilik sistemi, bu zaman içerisinde başarılı bir performans göstererek uzun vadede finansal piyasalara ve ekonomiye katkısının büyük olacağı açık bir şekilde ortaya çıkmıştır. Diğer yandan katılımcıların bu sisteme dahil olduktan sonra birikimlerinin fonlardaki değerlerinin düşük olması ve ekonomik yapıdaki dalgalanmalar nedeniyle sisteme olan güven ve inançları zedelemiştir. Bu durum bireysel emeklilik sisteminin ileriye yönelik gelişimini önemli ölçüde olumsuz etkilemiştir. 2008 krizinin ülkemizde bıraktığı izler BES bünyesinde bulunan fonları negatif yönde etkilemesine sebep olmuş ve bu durum doğaldır ki, sistemin büyümesine engel olan unsurların başında gelmiştir. Söz konusu dönemde hisse senedi fonlarındaki düşüş sözleşme sayılarında gerilemeye sebep olurken aynı zamanda katılımcıların tasarruflarını burada değerlendiren fon yönetim şirketlerinin de hataları sonucunda sistem sekteye uğramıştır. Kriz dönemlerinde tahvil değerlerinin artması da bireysel emeklilik sisteminin gelişimini olumsuz yönde etkilemiştir. Ülkemizde BES'in var olan büyüklügüü, emeklilik fonlarının genellikle kamu borçlanma senetlerinden meydana gelmesi ve finansal anlamda ürün çeşitliliğinin az olması küresel finans krizinin sistem üzerindeki olumsuz etkisini sınırlandırmıştır.

Bireysel emeklilik sisteminin küresel olarak yaygınlaşmasına neden olan temel unsur, sosyal güvenlik sisteminin görevini tam anlamıyla yerine getirememesi ve daha şeffaf bir sisteme duyulan gereksinimdir. Bireysel Emeklilik Sistemini kullanan G7 ülkeleri incelendiğinde, farklı uygulamaların olduğu gözlemlenebilmektedir. Sistemi genellikle zorunlu ve isteğe bağlı sistem olarak, iki temel başlık altında toplayabiliriz.

Metinde Tablolar kısmı incelendiğinde, katılımcıların sisteme giriş yaşları yıllara göre artış göstermiştir. Sözleşmelerin yürürlüğe girişlerinin yıllara göre dağılımlarına bakıldığında ilk zamanlar sisteme katılım az iken 2013 senesinden sonra sisteme katılan birey sayısında artış olduğu ve sistemden de çıkışların azaldığ 1 sonucuna ulaşılmaktadır. Katılımcıların sistemde geçirdikleri zaman dikkate alındığında, 4 ila 5 sene arasında yatırıma yönlendirilen fon büyüklüğünün en üst seviyede olduğu görülmüştür. Ayrıca yapılan swot analizinde, sistemin güçlü yanları arasında devlet katkısının uygulanması ve vergi avantajının bulunması sayılabilir. Ayrıca şeffaf yapı sayesinde katılımcıların, birikimlerinin nerelerde, ne şekilde değerlendiğini rahatlıkla takip edebilmelerine olanak verilmektedir. Buna karşılık, sistemin zayıf yönlerine ilişkin ise, erken çıkışlarda yönetim gider kesintilerinin olmasını, uzun dönemli bir yatırım aracı olmasını ve devlet katkısının tamamının alınabilmesi için en az 10 yıl sistemde kalma zorunluluğu ve 56 yaş sınırının olmasını gösterebiliriz.

Sistemin G7 ülkelerinde olduğu gibi ülkemizde de hem devlet hem de bireyler açısından çok sayıda faydasından söz etmek mümkündür. Ancak sistemin gelişimi açısından birtakım olumsuzluklar yaşandığı da yadsınamaz bir gerçektir. Özellikle ülkemizde finansal okur yazarlık düzeyinin artışı, hem katılımcı sayısına hem de fon büyüklüğüne katkı sağlayacaktır. Sistemin getirileri yine sistemin belirlediği kurallar çerçevesinde incelendiğinde, uzun vadeli birikimin özendirilmesi, fon getirisinin yüksek oluşu ve küçük tutarlarla dahi sistemde birikim yapan bireylerin sözleşme sonunda tasarruflarını ister tek ödemeyle, isterlerse aylık gelir şeklinde alabilme imkanı, sistemin Türkiye ve dünya genelinde tercih edilen bir tasarruf aracı olduğu gerçeğini ortaya koymaktadır. Sistem kendini günün gelişmelerine göre yenilemekte ve yatırımcıları sisteme giriş için teşvik etmektedir. Emeklilik şirketlerinin birleşmesi neticesinde daha büyük bir fon büyüklüğüne ulaşılmıştır. Bu durum yatırımcıların getirilerini artırmakta ayrıca devlet katkısının bulunması da sisteme duyulan güvenin artmasını sağlamaktadır. Sonuç olarak, sistemin Türkiye ve dünya genelinde tercih edilen bir tasarruf aracı olduğu, bu bağlamda sistemin gelişmekte olduğu ve sisteme olan üvenin arttığı sonucuna varılabilir.

\section{KAYNAKÇA}

APAK, S., \& TAŞCIYAN, K. H. (2010). Türkiye'de Bireysel Emeklilik Sisteminin Gelişimi. Ekonomi Bilimleri Dergisi, 121-129.

ARSLAN, S., \& ÇELIK, M. S., \& HAYKIR, Ö. (2018). Türkye'de ve Dünya'da Bireysel Emeklilik Sistemi Uygulamaları Üzerine Bir İnceleme. II. Uluslararası Multidisipliner Çalışmaları Kongresi (s. 28-39). Adana: Researchgate.

AYGÖREN, H., UYAR, U., MORALI, T., \& KELTEN, G. S. (2019). Yatırımcı ve Yönetim Penceresinden Bireysel Emeklilik Sistemi. İstanbul: Ekin Yayınevi.

BAYAR, Y., \& KILIÇ, M. (2014). Küresel Finansal Krizin Türkiye'de Bireysel Emeklilik Sistemine Etkileri. Insan ve Toplum Bilimleri Araştırmaları Dergisi, 246-264. 
BAYRAK SALANTUR, Ş. (2015). Bireysel Emeklilik Katılımcılarının Sistemden Erken Çıkma Riskinin Değerlendirilmesi. Hacettepe Üniversitesi Sosyal Bilimler Enstitüsü İşletme Anabilim Dalı Muhasebe Finansman Bilim Dalı, Yayımlanmamış Doktora Tezi

BLAKE, D., 2000. Does It Matter What Type of Pension Scheme You Have?, The Economic Journal, Vol.110, No.461, F46-81.

CAN, Y. (2010). Bireysel Emekliliğin Türkiye'deki Durumu ve Gelişimi. Ekonomi Bilimleri Dergisi, 139-146.

CAN, Y., \& EYİDIKKR, U. (2019). Bireysel Emeklilik Sisteminde Otomatik Katılımın Türkiye'de Gelişimin İzlenmesi. Finans Ekonomi ve Sosyal Araştırmalar Dergisi, 626-642.

EMEKLİLİK GÖZETİM MERKEZİ. (2017). Bireysel Emeklilik Sistemi Gelişim Raporu. İstanbul: Emekliik Gözetim Merkezi.

EMEKLİLİK GÖZETİM MERKEZİ. (2020, 05 15). Emeklilik Gözetim Merkezi. 05 15, 2020 tarihinde Emeklilik Gözetim Merkezi: http://www.egm.org.tr/bireysel-emeklilik/tarihce/ adresinden alındı

INAN, M. (2019). Türkiye'de Bireysel Emeklilik Sistemi. Konya: Çizgi Yayınevi.

İNNECİ, A. (2013). Bireysel Emeklilik Sisteminde Yapılan Yeni Düzenlemeler ve Değerlendirilmesi. Ç.Ü. Sosyal Bilimler Enstitüsü Dergisi, 105-120.

İŞSEVEROĞLU, G., \& HATUNOĞLU, Z. (2012). Türkiye'de Bireysel Emeklilik Sisteminin Makro Ekonomik Dinamiklere Etkisi Kapsamında Swot Analizi. Muhasebe ve Finansman Dergisi, 155-174.

KARA, S., \& YILDIZ, Y. (2016). Türkiye'de Bireysel Emeklilik Sistemi: 2012 Sonrası Yapılan Reformlar ve Beklentiler. İşletme ve İktisat Çalışmaları Dergisi, 23-45.

MERAL, H., \& ARICAN, E. (2020). Bireysel Emeklilik Sistemine Otomatik Katılım: Türkiye İçin Bir Uygulama. Finansal Araştırmalar ve Çalışmalar Dergisi, 190-212.

SERMAYE PIYASASI KURULU. (2020, 05 15). Sermaye Piyasası Kurulu. 05 15, 2020 tarihinde Sermaye Piyasası Kurulu: http://www.spk.gov.tr adresinden alındı

SEYFULlAHOĞULlARI, A., \& DEMİRHAN, B. (2016). Bireysel Emeklilik Sistemine Katkıları Açısından Vergi Avantajı İle Devlet Katkısının Karşılaştırılması. Marmara Sosyal Araştırmalar Dergisi, 23-50.

ŞAHIN, O., \& BAŞARIR, Ç. (2019). Bireysel Emeklilik Sirketlerinin Finansal Reformlarının Değerlendirilmesi: Türkiye Örneği. Yönetim Bilimleri Dergisi, 211-229.

ŞATAF, C., \& YILDIRIM, O. (2019). Türkiye'de Bireysel Emeklilik Sistemi'nin (BES) Algılanma Düzeyi: Ordu İli Örneği. Selçuk Üniversitesi Sosyal Bilimler Meslek Yüksekokulu Dergisi, 572-588.

T \& T Sigorta Bireysel Emeklilik. (2020, 05 10). Dünyadaki Bireysel Emeklilik Sistemleri. 05 10, 2020 tarihinde $\mathrm{T} \& \mathrm{~T}$ Sigorta Bireysel Emeklilik: http://www.ttemeklilik.com/dunyadaki-bireysel-emekliliksistemleri.html adresinden alındı

TAPIA, W. (2008). Description of Private Pension Systems. OECD Publishing, 13.

TUNALI, D. (2016). Anadolu Üniversitesi Akademik Personelinin Bireysel Emeklilik Sistemine Bakışı. Işsletme ve İktisat Çalışmaları Dergisi, 98-105.

WIKIPEDI. (2020, 05 11). G7. $5 \quad 11,2020$ tarihinde Wikipedi Özgür Ansiklopedi: https://tr.wikipedia.org/wiki/G7\#: :text=Grup $\% 20 \mathrm{Almanya} \% 2 \mathrm{C} \% 20 \mathrm{ABD} \% 2 \mathrm{C} \% 20 \mathrm{Birle} \% \mathrm{C} 5 \% 9 \mathrm{Fik} \% 2$ 0Krall\%C4\%B1k,(263\%20trilyon\%20\%24)\%20olu\%C5\%9Fturmaktad\%C4\%B1rlar. adresinden alınd

YALÇIN, Ö., \& MARŞAP, B. (2019). Türkiye'de Bireysel Emeklilik Sistemi: Modelleme ile Gelişimin Değerlendirilmesi. İ̧sletme Araştırmaları Dergisi, 864-875.

YEMEZ, İ., \& AKDOĞAN, M. Ş. (2019). Bireysel Emeklilik Sistemi Satın Alma Tercihlerinin Demografik Değişkenlere Göre İncelenmesi. C.Ü. Íktisat ve İdari Bilimler Dergisi, 104-118. 
YUMURTACI, B., \& ONURSAL, F. S. (2019). Kisttlar Teorisi-Düşünce Süreçleri İle Bireylerin Bireysel Emeklilik Sisteminden Ayrılma Nedenlerinin Analizi. Işsletme Araştırmaları Dergisi, 3269-3282. 